\title{
A Model for a Faculty Development Course Redesign Summer Working Group
}

\section{Dr. Michelle M Blum, Syracuse University}

Dr. Blum is interested in research in improving undergraduate engineering education; including development of inquiry based activities for first year engineering courses, improvement of student design projects, hands-on activities, professional skills development and inclusion and outreach activities. Dr. Blum also specializes in high performance materials development and characterization for tribological (friction and wear), structural, and biomedical applications.

\section{Dr. Katie D. Cadwell, Syracuse University}

Katie Cadwell is an Associate Teaching Professor in the Department of Biomedical and Chemical Engineering at Syracuse University, where she has taught Chemical Engineering core courses since 2011. After receiving Chemical Engineering degrees from the Missouri University of Science and Technology (B.S.) and University of Wisconsin-Madison (Ph.D.), she pursued a postdoctoral position in engineering education and outreach with the Interdisciplinary Education Group of the Materials Research Science and Engineering Center at UW-Madison. Prior to moving to Syracuse, she taught for several years at Madison Area Technical College. Her interests include development of engineering faculty attitudes and pedagogy, teaching professional skills in the engineering classroom, and engineering outreach at the K-12 level.

\section{Dr. Julie M. Hasenwinkel, Syracuse University}

Professor and Chair, Department of Biomedical and Chemical Engineering College of Engineering and Computer Science Syracuse University Syracuse, NY 13244 


\title{
A Model for a Faculty Development Course Redesign Summer Working Group
}

\begin{abstract}
Overview: This Evidence-Based Practice Paper describes a professional development opportunity offered to engineering and computer science faculty at Syracuse University in the summer of 2019 that focused on improving delivery and assessment at all grade levels of course instruction. This was a continuation of a project developed by a grant-supported team originating as an opportunity for faculty to modify first year or gateway classes. For this subsequent offering, the opportunity was open for any faculty to participate in a Course Redesign Summer Working Group.

Goals: The goals of the working group were to further educate faculty on best practices in teaching and assessment; provide a forum for sharing teaching practices; to help faculty implement best practices, in the form of student-active pedagogies and defining and assessing student learning outcomes; and to encourage faculty to test the success of these changes in their classrooms in the 2019-2020 academic year.

Motivation: The motivation for creation of the working group was to enhance prevalence of active learning in engineering classes in order to improve both retention and graduation rates, thus keeping these students in the engineering pipeline.
\end{abstract}

Method: The team created an intensive summer program where faculty had to commit to attend a kick-off meeting, a minimum of four 2-hour working sessions, and a mandatory final presentation. During these sessions faculty benefited from: guest speakers on developing course outcomes, teaching methods, and assessment techniques; access to a forum for faculty to discuss adapting methods to their various subjects, including potential pitfalls and best practices; receiving peer and technical feedback and support for their new ideas; accountability from their peers; dedicated time and space to work on their new ideas. For a course redesign plan faculty had to develop student-learning outcomes, an assessment plan, and an implementation plan for the course changes. In addition, for fully participating, faculty received a summer salary supplement and an additional supplement after implementing the class changes and assessing the success of those changes.

Twenty faculty participated in the summer 2019 program with 95\% of the workshop participants meeting all of the summer program requirements, including presenting their work/plans at the final summer meeting. During the 2019-2020 academic year, faculty implemented their course changes and were required to submit a final deliverable focusing on assessment of the success of their course change. 
Assessment: The success of the program was determined by the implementation and assessment of the proposed changes each faculty incorporated into their course. The faculty were surveyed to determine the likelihood that they would have revised their course without the support and accountability that the Redesign Working Group provided. Since this was a continuation of a recently developed program, a comparison was made between project outcomes and faculty attitudes between the first and second offerings. From the survey feedback and the final assessment deliverables it was shown that the program was successful, and we will continue to offer it to faculty. In addition, we plan to share the model and lessons learned with other colleges and universities.

\section{Introduction}

The limitations of students learning styles when participating in archaic and passive lecturebased classrooms is well documented in engineering education [1-4]. There is a plethora of evidenced-based research in education which shows student understanding and retention is increased when using more modern teaching methods; such as Active Learning [5], Collaborative Learning [6], Cooperative Learning [7] and Problem-based learning (PBL) [8]. Historically faculty in engineering disciplines have tended to teach classes in more traditional lecture formats, and there has not been a widespread institutional culture of opportunity for faculty to participate in professional development. Beginning around the 1990's, there was a national effort to develop programs to involve faculty to train them to use more varied teaching methods [9]. Previous faculty development programs include SUCCEED and ECSEL Coalitions [10], FOUNDATION Coalition [11], and GATEWAY Coalition [9]. These entities work to develop and execute professional development programs for faculty to train them in diverse and modern teaching approaches.

One type of program that has shown positive progress is based upon summer workshops or institutes for faculty devoted to teaching practices. One example is the National Academies Summer Institutes (SIs) [12, 13]. Beginning as a biology summer institute, this program has been operating since 2004. The SIs are intensive multi-day workshops were both faculty and staff can receive training in evidence-based approaches to teaching courses. This large-scale institute has shown nationwide success. Another example of a nationally available teaching workshop series for faculty is the National Effective Teaching Institutes [14]. These three-day workshops give participating faculty information and some practice in course planning, active learning techniques and learning assessments. They have different levels, ranging in focus from new faculty to experienced professors.

This paper describes an engineering focused course development summer working group provided by a College-wide faculty development program at the College of Engineering and Computer Science (ECS) at Syracuse University. The NSF-supported faculty development project, Enhancing the Climate for Persistence and Success in Engineering (ECliPSE), partly 
focuses on creating a culture that supports development of pedagogical awareness and personal experimentation by faculty through providing opportunities for faculty to interact around teaching, offering pedagogy seminars and workshops, and generally maintaining a continued focus in the college on improving teaching practices. Through ECliPSE, a program was piloted in 2017 called the Summer Gateway Course Redesign Working Group. For the first offering of the workshop the focus was to aid faculty who teach gateway engineering courses (primarily $1^{\text {st }}$ and $2^{\text {nd }}$-year courses) to develop and implement student-active teaching techniques in those courses. For the second offering of the workshop, the opportunity was open for any ECS faculty to participate. The purpose of the 2019 summer working group was for faculty to redesign classes to include or enhance students' active learning, develop or refine assessment of student outcomes, and implement and assess these changes in the 2019-2020 Academic Year. There are several key differences between this program and the national programs. Specifically, this program required faculty to apply based on working on a specific project for a specific course, whereas nationwide programs accept faculty without this stipulation. Additionally, whereas nationwide programs last anywhere from a day to at most a full work week, the major part of this workshop lasted two full months so that faculty would have substantial time to work on their course projects independently outside of the meetings. Finally, the college has been developing a culture of teaching and learning excellence for several years, so there was less need to focus on influencing faculty attitudes to favor active learning or otherwise convince them to use active techniques. Rather, this workshop sought to provide support, time and resources for faculty already convinced of the value of active learning to make improvements to their courses.

In this paper, relevant components of the ECliPSE program are detailed, and then the logistics of the 2019 Summer Gateway Course Redesign Working Group are described, including selection of invited faculty, the specific required deliverables, weekly meetings logistics, and examples of individual projects. Evaluation of the success of the Summer Gateway Course Redesign Working Group as determined by the completion of projects and assessments and feedback from individual faculty participating in the program is presented. Then a comparison is made between the first and second offerings of the workshop. Finally, the future direction of the program will be discussed.

\section{ECliPSE Overview}

The primary goals of the ECliPSE program are to raise faculty awareness of their personal impact on students' learning outcomes and attitudes; to incorporate more active and studentcentered learning earlier in the curriculum; and to improve the classroom environment and student learning, leading to increased student persistence. The approach has been rooted in faculty development in teaching and learning [15]. Since March 2013, over 70 faculty development opportunities have been organized and offered within the college and nearly $75 \%$ of ECS faculty have participated. Examples of these activities include multi-day workshops, half-day workshops, summer workshops, extended working groups, invited lectures, semester- 
long faculty book clubs, and informal teaching and learning lunches. Faculty consistently report gains in knowledge, confidence, and likelihood of trying new pedagogies after participating in the grant-funded activities. This work has translated into significant change within the college. Over thirty courses have been redesigned or significantly revised, including all gateway courses in the college. Retention and graduation rates have improved over the past five years with the $1 \mathrm{st}$ year retention rate increasing by 3.4 percentage points, the $2^{\text {nd }}$ year retention rate increasing by 8.8 percentage points, the 4 year graduation rate increasing by 9 percentage points and the 6 year graduation rate increasing by 7.1 percentage points. But perhaps the biggest and most enduring change has been a shift in the culture within the college related to teaching and learning. ECS faculty are much more visibly engaged in continuously improving their teaching, learning and implementing best practices, and improving student learning outcomes, and this has diffused well beyond the $1^{\text {st }}$ and $2^{\text {nd }}$ year courses, which were the original focus of the grant.

\section{Working Group Overview}

In the spring of 2019, all college faculty (ca. 100) in ECS were invited to apply for participation in the Summer Gateway Course Redesign Working Group. Some areas that were encouraged for course redesign included first year courses, gateway courses, sequential pre-requisite courses and instructors with new courses. To be considered for the program, applicants needed to submit a proposal. Included in the proposal were the following elements:

- The course name, description and whether it was a required course or an elective;

- The purpose for revising or reinvigorating this course;

- Initial ideas for course revision (including flipping the classroom, adding hands-on activities, adding project based learning activities, adding a project to the course);

- Initial plans for review/revision of student outcomes;

- Initial plans to assess the project's success and/or the improvement in student learning.

Finally, in order to participate in the Gateway Course Redesign Working Group, faculty had to agree to participation requirements. These included the following:

- Attendance and participation at a Kick-off Meeting;

- Attendance and participation at a minimum of four working group sessions (nine working sessions were provided through June and July to accommodate faculty summer schedules);

- Submission of written plans for their project midway through and at the end of the summer program;

- Participation in a mandatory final presentation, which was held at the beginning of the fall semester. 
All faculty who met the proposal requirements and agreed to the participation requirements were admitted. Two faculty members co-facilitated the working group, one of whom was a Co-PI from the ECliPSE team. Each participant completed a lengthy schedule poll for the summer such that the co-facilitators could devise a schedule of roughly weekly meetings that would allow 20 faculty members to attend a minimum of four working sessions. Participants were enrolled in a Blackboard group set-up for sharing files and participating in discussions. At the weekly two hour meetings, each session began with mandatory 1-minute updates by each faculty participant, who summarized what they did since their last meeting and what they hoped to do next. This practice helped to build accountability among peers, and the time limit was strictly enforced, encouraging faculty to focus on reporting their primary goals. Updates were followed by a 30-45 minute "skill building" session. During this time, faculty engaged in discussions of assessment or pedagogical techniques, viewed tutorials or presentations, participated in demonstrations of techniques of interest from the student perspective, engaged in "pair-and-shares", and prepared brief written activities to explore how a technique might be applied to their course. The content was primarily based upon participating faculties' interests, but the first three sessions were all on assessment topics in the hopes that each faculty member could attend at least one of those sessions. A list of weekly topics is given in Table 1. After "skill building", faculty were given the rest of the time to work on their projects, ask more in-depth questions of presenters/demonstrators, interact with other faculty working on similar projects or with expertise in a technique they were interested in.

Table 1: Summary of 2019 Course Redesign Summer Working Group Schedule and Presentation Topics for each meeting

\begin{tabular}{|c|l|}
\hline Week & Guest Speaker: Working Session Topic / Deliverable Due \\
\hline 0 & Co-facilitators: Kick-off (Main Session \& Make-up) \\
\hline 1 & Staff, Center for Teaching \& Learning Excellence: Outcomes \& Assessment Part 1 \\
\hline 2 & Staff, Center for Teaching \& Learning Excellence: Outcomes \& Assessment Part 2 \\
\hline 3 & Staff, Center for Teaching \& Learning Excellence: Outcomes \& Assessment Part 3 \\
\hline 5 & Faculty Participant: Implementing Problem Based Learning \\
\hline 5 & Intermediate written deliverables due \\
\hline 6 & Co-facilitator \#1: Implementing Process-Oriented Guided Inquiry Learning \\
\hline 7 & Staff, Online Learning Services: Digital Teaching Tools - Kahoot \& Flipgrid \\
\hline 8 & Staff, Online Learning Services: Lecture screen capture and Blackboard features \\
\hline 8 & Co-facilitator \#2: Designing \& Implementing Rubrics for Anything \\
\hline 9 & No speaker: Make-up Session \& Open Forum \\
\hline $\begin{array}{c}\text { beginning of } \\
\text { fall semester }\end{array}$ & Final summer deliverables due uploaded to Blackboard \\
\hline $\begin{array}{c}\text { beginning of } \\
\text { spring semester }\end{array}$ & Assessments/Reflections for faculty projects implemented in Fall 2019 due \\
\hline $\begin{array}{c}\text { beginning of } \\
\text { summer term }\end{array}$ & Assessments/Reflections for faculty projects implemented in Spring 2020 due \\
\hline
\end{tabular}


The aforementioned required written deliverables included:

- Intermediate Deliverables

- Draft of New/Revised Student Learning Outcomes

- Brief Summary of Project Plans and Progress to Date

- Preliminary Assessment Plan to evaluate Student Learning Outcomes

- Final Summer Deliverables

○ Finalized Student Learning Outcomes

- Project Implementation Plan to detail further actions necessary to successfully implement summer project during Fall 2019 or Spring 2020 semester

- Finalized Assessment Plan designed to determine to what degree Student Learning Outcomes have been met

Participants who completed the summer participation and written deliverable requirements received a $\$ 2,000$ summer salary supplement (paid through the ECliPSE grant). Finally, an additional \$2000 supplement could be earned after implementing class changes, assessing, and reporting about the success of those changes. Those requirements included:

- Completing a written assessment of the defined Student Learning Outcomes from the Final Summer Deliverables to determine the success of the course changes.

- Completing a written reflection of the Course Redesign Working Group process.

Faculty who taught courses in the fall semester of 2019 had to turn in these final requirements at the beginning of the spring 2020 semester; and faculty who taught courses in the spring semester of 2020 had to submit them by the beginning of the next summer term.

\section{Program Metrics}

Table 2 summarizes the summer project metrics. The Project Type was defined as follows:

- Active Learning = instructional method that engages students in the learning process. Examples: online homework, worksheets in classroom, flipped-classrooms.

- Collaborative Learning = instructional method where students work together in the classroom in informal groups.

- Problem Based Learning = instructional method where relevant problems are introduced at the beginning of the instruction cycle and used to provide the context and motivation for the learning that follows.

- Hands-On Activities = instructional method where students perform projects or demonstrations within the context of the classroom to learn about a topic.

- Student Outcomes = major focus on tying course content to student outcomes. 
- Other $=$ creation or revision of lab activities or assessment prerequisite quizzes or exams.

The Project Scope was defined as either Course Revisions, Course Component, or Course Redesign. A Course Revision Scope changed already existing parts of a course. Examples include updating or expanding existent assessment tools or student projects. A Course Component Scope was a project that changed or added a major element of a course, for example adding new projects or topics, or using a new technique for a portion of the course. A Course Redesign Scope involved entirely changing instructional methods and implementing major changes in order to re-make the entire courses, from a content and/or delivery perspective. Twenty faculty members (10 tenured/tenure-track and 10 teaching-track) drawn from all of the ECS departments were accepted into the group and agreed to the program requirements. The majority of the projects $(65 \%)$ focused on upper level engineering courses taken at the junior, senior or graduate level.

A summary of faculty participation can be seen in Figures 1 and 2: the vast majority (90\%) of faculty were able to meet the minimum working session requirement of 4 meetings, and half of the participants attended more sessions than were required. Of the two that did not meet the minimum, one participant discontinued their participation early when they realized they would not be able to balance the working group requirements with their summer fieldwork. Another faculty member had their summer fieldwork schedule unexpectedly change and was unable to make their fourth planned session. Thus, one of the co-facilitators arranged a one-on-one makeup session to explore a pedagogical technique that the participant was interested in implementing and the co-facilitator had experience in. With this accommodation, the participant was able to complete all remaining requirements.

In general, the scheduling to accommodate 20 faculty members during the summer (up from 14 participants in the first offering in 2017) required some creativity and effort, even when requesting that participants be generous with their schedule-poll responses. A make-up kick-off session was added in week zero because no single date and time could be found that all 20 faculty members could meet at the beginning of the workshop. A second session was added to the eighth week to make sure that three of the participating faculty members would be able to make their required four working sessions. These accommodations were planned during the initial workshop design and organization phase. As the summer progressed, attendance at the weekly sessions gradually decreased (Figure 2). Thus it was fortunate that the three sessions on outcomes and assessment had been frontloaded in the first three weeks. As intended, all participants were able to attend at least one of the assessment-focused sessions, even though it was not explicitly required. 
Table 2: Summary of faculty projects worked on during the Summer Working Group

\begin{tabular}{|c|c|c|c|c|c|}
\hline Course & $\begin{array}{l}\text { Project } \\
\text { Scope }\end{array}$ & Project Type & $\begin{array}{l}\text { Faculty } \\
\text { Track }\end{array}$ & $\begin{array}{l}\text { Curriculum Major } \\
\& \text { Year }^{1}\end{array}$ & $\begin{array}{l}\text { Project } \\
\text { Implemented }\end{array}$ \\
\hline Computer Architecture & Revisions & $\begin{array}{l}\text { Student } \\
\text { Outcomes }\end{array}$ & Teaching & CompEng (Jr) & Fall 2019 \\
\hline $\begin{array}{l}\text { Chemical Engineering } \\
\text { Lab } 2\end{array}$ & Revisions & Other & Pre-Tenure & Chem (Sr) & Fall 2019 \\
\hline $\begin{array}{l}\text { Statistical Mechanics \& } \\
\text { Thermodynamics }\end{array}$ & Revisions & $\begin{array}{l}\text { Student } \\
\text { Outcomes }\end{array}$ & Tenured & Chem (Jr, Sr, G) & Spring 2020 \\
\hline $\begin{array}{l}\text { Transportation } \\
\text { Engineering }\end{array}$ & Revisions & $\begin{array}{l}\text { Active } \\
\text { Learning } \\
\end{array}$ & Tenured & $\mathrm{Civ}(\mathrm{Sr}, \mathrm{G})$ & Fall 2019 \\
\hline Electrical Microgrids & Component & $\begin{array}{l}\text { Hands-on } \\
\text { Activities } \\
\end{array}$ & Teaching & Elec $(\mathrm{Sr}, \mathrm{G})$ & Fall 2019 \\
\hline $\begin{array}{l}\text { Chemical Engineering } \\
\text { Thermodynamics I }\end{array}$ & Component & $\begin{array}{l}\text { Student } \\
\text { Outcomes, } \\
\text { Other }\end{array}$ & Teaching & Chem (So) & Spring 2020 \\
\hline Data Analysis & Component & $\begin{array}{l}\text { Active } \\
\text { Learning }\end{array}$ & Teaching & $\operatorname{Mech}(\mathrm{Jr}, \mathrm{Sr})$ & Fall 2019 \\
\hline Statics & Component & Other & Pre-Tenure & $\begin{array}{l}\text { Aero, Bio, Civ, Env, } \\
\text { Mech (So) }\end{array}$ & Spring 2020 \\
\hline $\begin{array}{l}\text { Introduction to } \\
\text { Engineering \& Computer } \\
\text { Science }\end{array}$ & Component & $\begin{array}{l}\text { Problem- } \\
\text { Based } \\
\text { Learning }\end{array}$ & Tenured & $\operatorname{Bio}(F)$ & Fall 2019 \\
\hline $\begin{array}{l}\text { Chemical Reaction } \\
\text { Engineering }\end{array}$ & Component & $\begin{array}{l}\text { Active } \\
\text { Learning }\end{array}$ & Tenured & Chem (Sr, G) & Fall 2019 \\
\hline Project Management & Redesign & $\begin{array}{l}\text { Hands-on } \\
\text { Activities }\end{array}$ & Teaching & $\operatorname{Mech}(\mathrm{Sr}, \mathrm{G})$ & Fall 2019 \\
\hline $\begin{array}{l}\text { Introduction to } \\
\text { Engineering \& Computer } \\
\text { Science }\end{array}$ & Redesign & $\begin{array}{l}\text { Active } \\
\text { Learning }\end{array}$ & Teaching & $\operatorname{Mech}(F)$ & Fall 2019 \\
\hline Data Structures & Redesign & $\begin{array}{l}\text { Active } \\
\text { Learning }\end{array}$ & Teaching & $\begin{array}{l}\text { CompSci, CompEng, } \\
\text { Elec, SIS (Jr) }\end{array}$ & Fall 2019 \\
\hline $\begin{array}{l}\text { Fundamentals of Linear } \\
\text { Systems }\end{array}$ & Redesign & $\begin{array}{l}\text { Active } \\
\text { Learning }\end{array}$ & Teaching & $\begin{array}{l}\text { Bio, CompEng, Elec } \\
(\text { So, Jr) }\end{array}$ & Fall 2019 \\
\hline $\begin{array}{l}\text { Water Resources } \\
\text { Engineering }\end{array}$ & Redesign & $\begin{array}{l}\text { Active } \\
\text { Learning }\end{array}$ & Teaching & Civ, Env (Jr) & Spring 2020 \\
\hline $\begin{array}{l}\text { Bioengineering } \\
\text { Fundamentals }\end{array}$ & Redesign & $\begin{array}{l}\text { Active } \\
\text { Learning }\end{array}$ & Teaching & Bio (So) & Fall 2019 \\
\hline $\begin{array}{l}\text { Experimental Methods in } \\
\text { Chemical Engineering and } \\
\text { Bioengineering }\end{array}$ & Redesign & $\begin{array}{l}\text { Active } \\
\text { Learning }\end{array}$ & Pre-Tenure & Bio, Chem (So) & Spring 2020 \\
\hline $\begin{array}{l}\text { Polymer Science and } \\
\text { Engineering }\end{array}$ & Redesign & $\begin{array}{l}\text { Collaborative } \\
\text { Learning }\end{array}$ & Pre-Tenure & Bio, Chem (Jr, Sr, G) & Fall 2019 \\
\hline $\begin{array}{l}\text { Certified Security by } \\
\text { Design \& Assurance } \\
\text { Foundations }\end{array}$ & Redesign & $\begin{array}{l}\text { Active } \\
\text { Learning }\end{array}$ & Tenured & CompSci (Sr, G) & Fall 2019 \\
\hline
\end{tabular}

${ }^{1}$ Curriculum Years are Freshman (F), Sophomore (So), Junior (J) Senior (Sr) and Graduate (G). Majors are Aerospace Engineering (Aero), Bioengineering (Bio), Chemical Engineering (Chem), Civil Engineering (Civ), Computer Engineering (CompEng), Computer Science (CompSci), Electrical Engineering (Elec), Environmental Engineering (Env), Mechanical Engineering (Mech), Systems \& Information Science (SIS) 
Figure 1: Number of working sessions attended by faculty, of 9 possible sessions during 8 weeks

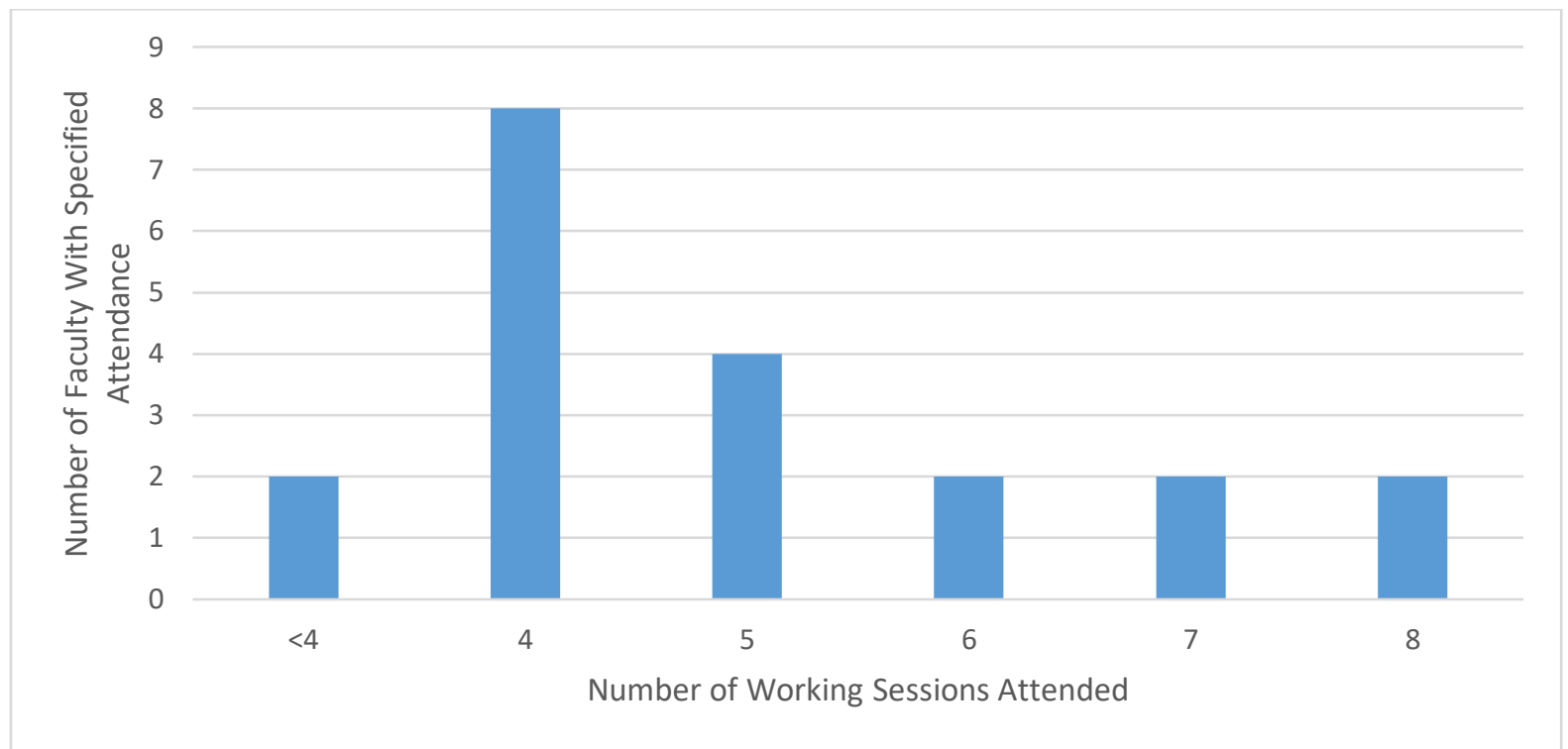

Figure 2: Participant attendance at each of the Kick-Off Meetings $(0 \mathrm{~A}, 0 \mathrm{~B})$ and regular working sessions

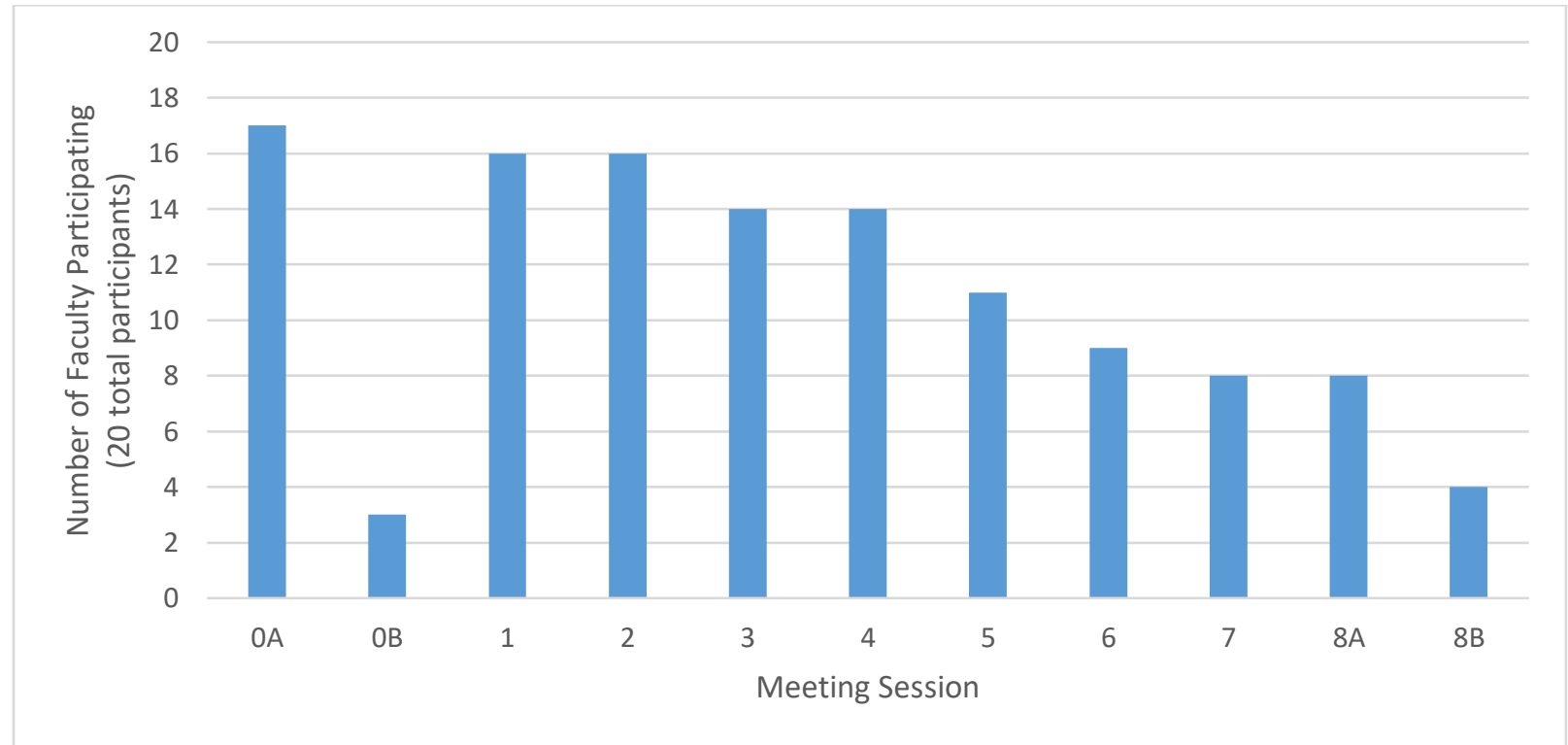

\section{Project Examples}

Of the 19 projects completed at the end of the summer, $21 \%$ were Course Revisions, $32 \%$ were Course Component changes and $47 \%$ were larger Course Redesigns. There were a variety of projects spanning all of the engineering disciplines, with $37 \%$ of the classes being at the freshman and sophomore level and 63\% of the classes at the upper levels (junior, senior, 
graduate). The majority ( $74 \%$ ) of the classes were required in at least one undergraduate curriculum, with only $26 \%$ of the classes being engineering electives.

One Course Revision took place in an upper level required Chemical Engineering Laboratory class. For the workshop, the pre-tenured faculty modified already existing laboratories to incorporate aspects of scale-up design, engineering economics, and process safety into each project. The instructor also added new elements of professionalism, teamwork, and lab safety into the already built course structure. Finally, course level assessments were changed from the old ABET Student Learning Outcomes A thru K to the newly adopted ABET Outcomes 1 thru 7. This is a perfect example of a course revision because new elements were added to an already existing course and the assessment criteria was updated.

An example of a Course Component project occurred for a required freshmen introduction to engineering course for biomedical engineers. The tenured instructor's summer project was the redesign of one of the three student team projects that together form the course. The course was already being taught in a Project-Based Learning (PBL) format, with on-demand lecture content. However, the prior PBL project that this new one was replacing involved Matlab coding but no hands-on components. The new project asked students to use a microcontroller and the Python programming language to design a wearable assistive technology device that could control a computer cursor with both left and right mouse, and the WASD and space keys without the use of individual fingers. This major component change (roughly one-third of the course) was done to the course to incorporate the benefit of a "hands-on" design problem, as student teams built and tested their prototypes to play and compete in computer games.

An example of a Course Redesign that was accomplished during the workshop was the remaking of an entire course in Technology Management. This course is an upper level (seniors and graduate students) elective course in the mechanical engineering department, taught by a teaching-track faculty. For the course redesign, the instructor selected a new textbook, created weekly understanding checkpoints in the form of online quizzes, developed twelve new case studies, and created a final culminating project. Although the instructor had taught the course previously, nearly all of the teaching techniques and the organization of the course were completely redone.

Faculty used a variety of methods to assess the student performance related to changes made in their courses, the goals of which varied from increased student engagement to specific technical student outcomes. Assessments ranged from summative exams, to scoring of homework assignments or in-class worksheets, to more qualitative information from student surveys. The specific results of these assessments also varied from faculty to faculty. Some faculty reported overall positive assessment metrics, others found assessment data to be mixed, and yet others were unable to draw firm conclusions from their assessment data and suggested refining the assessment method in the next course offering. The success of the workshop, however, can be 
gauged by continued faculty efforts to implement changes to improve student outcomes and assess student performance.

An example of assessment of student engagement was from student opinion surveys in the introduction to engineering course for biomedical engineers. The students in this course reported high levels of engagement, enthusiasm and preparedness via the surveys. An example of assessment of specific technical student outcomes comes from the chemical engineering laboratory given as the Course Revision example earlier. In order to introduce new elements of professionalism, teamwork, and lab safety into the course structure, each lab team was required to perform a thorough safety review by using a modified form that was derived from a management-of-change (MOC) process for industrial research and development. The faculty member reported that this change resulted in an increased focus by the students on lab safety relative to the fall 2018 course offering. Only one student team in 2019 was penalized for a lack of safety-related professionalism at the beginning of the semester, and not again afterwards, representing a marked improvement over previous student performance.

Faculty also solicited student feedback as formative assessment. One faculty member asked students to write an in-class reflection after each lesson, in the form of "Wow...Duh...Hmm". In the reflection, students were asked to fill in three boxes: (1) Wow: I didn't know that! (2) Duh: everyone knows that and (3) Hmm: I'd like to review/learn more about that. The responses were reviewed prior to the next class, so that adjustments to the lesson could be made if necessary. Thus this faculty member used this activity as a formative assessment to encourage student reflection and to inform the faculty's class plans. An example of a student reflection is shown in Figure 3.

Figure 3: Examples of student responses for a formative reflection assessment WOW...DUH...HMM

Use the chart below to record your thoughts about today's lesson.

\begin{tabular}{|c|c|c|}
\hline wow: I did not know that! & DUH: I already knew that! & $\begin{array}{l}\text { HMMMM: I'm a little confused about or' } \\
\text { would like to learn more about thatl }\end{array}$ \\
\hline $\begin{array}{l}\text { Definition and understanding } \\
\text { of dimension }\end{array}$ & Units & $\begin{array}{l}\text { The three groups } \\
\text { of evantities }\end{array}$ \\
\hline $\begin{array}{l}\text { Dimensional symbols } \\
\text { soch as matter, electric } \\
\text { corrent, and light }\end{array}$ & $\begin{array}{l}\text { US sistem / SI system } \\
\text { conversions }\end{array}$ & $\begin{array}{l}\text { Mass Flowrate } \\
\text { Volume Flowrate }\end{array}$ \\
\hline 7 primaly dimensions & & \\
\hline
\end{tabular}




\section{Program Offerings Comparison}

This workshop was an iteration of a program run two years prior [16]. Based upon facilitator experience from the first iteration, several organizational changes were made. The 2017 offering focused on first year and gateway courses, whereas the 2019 workshop was opened to faculty teaching upper division courses. With the majority of projects in 2019 focused on upper division courses, there was clearly interest by faculty in making improvements to those courses as well.

Being somewhat disappointed in 2017 that many participants did not clearly tie improvement projects to student outcomes, the 2019 program focused on being more prescriptive about a focus on assessment. As part of the deliverables, faculty were required to address student outcomes in their project design and then assess student outcomes for their implementation, and encouraged to use a quantitative assessment metric of student outcome attainment. Of the twelve faculty who implemented and assessed their projects in the fall 2019 semester, eleven had some quantitative assessment of students' performance on desired outcomes, based upon student work (submissions from faculty implementing courses in the spring 2020 semester are pending at the publication date). Faculty also included a good deal of qualitative/observational assessment, particularly assessment of student attitudes.

The final major difference between the first and second workshops was the restructuring of the stipends. For the two offerings, the amount of the stipend remained the same. However, for the 2017 offering, allocation of payment was shifted more towards the end of the summer. With faculty earning $75 \%$ of the stipend for completing the summer workshops and $25 \%$ of the stipend for completing semester implementation and assessment. For 2019, the stipends were restructured to them 50/50 instead of 75/25, in the hopes that this would encourage reporting on the implementation and assessment of their projects. In 2017, 79\% of participants fully completed the projects (summer plus semester implementation and assessment), split as 75\% (6/8) in the fall semester and 83\% (5/6) of spring semester projects. In fall $2019,92 \%$ of faculty submitted summaries of their implementations and assessments (12/13). There are six faculty teaching their courses in the spring 2020, on which the authors cannot yet report. The reallocation of the stipend payment seems to imply better completion to date, but small participant numbers preclude declaring a strong direct relationship.

Additional organizational changes were applied between the two offerings largely based on faculty feedback from the first workshop. Specifically in 2017, faculty commented on using a better room for breaking into groups. This was addressed in 2019 by using a collaborative classroom instead of a small conference room. Another change was the organization and support offered for the deliverables. The 2019 offering saw the addition of intermediate deliverables earlier in the summer, which allowed more time for faculty to receive feedback. In addition, support was offered by providing much more detailed descriptions of the deliverables, with examples, and even optional templates. Another major addition was the increase in reporting to 
the group. In 2019, working sessions began by each faculty participant giving 1-minute updates about the progress of their project. The final change faculty commented on in 2017 was being provided more structured work time vs. presentations. For the 2017 offering, there were fewer guest presentations, but they were longer, sometimes accounting for an entire working session, and were more lecture-based. In 2019, each working session was more balanced, keeping guest presentations to 45 minutes maximum, including more faculty participation and engagement during those presentations, and faculty were allowed the rest of the meeting to actively work on their projects.

\section{Discussion and Future Workshop Directions}

As part of the final assessment to conclude the group requirements, faculty were asked to submit reflections of their experience in the program. The reflections served as a way for faculty to express their thoughts about the summer working group and to provide feedback to the organizers about positive features of the workshops and potential future improvements.

Three main themes appeared in most of the 2019 faculty reflections, specifically the benefits of (1) the organized short presentations at the beginning of each workshop, (2) group accountability by active reporting and (3) self-imposed higher expectations supported by the stipend.

"Skill building" time - Faculty shared that they really benefitted from the 45 minutes "skill building" time, particularly the short presentations about and demonstrations of education pedagogy, techniques and assessment. The topics were chosen specifically to focus more on the practical aspects of implementation of a technique or tool, not necessarily convincing faculty of its benefits. One faculty quoted "I really enjoyed all of the guest speakers. I learned the most from the speakers on assessment, rubrics and gamification tools (Kahoot). I think the topics were varied. I also think that each speaker did a very good job of speaking to the practical application and implementation of each topic. No one spent a long time discussing the theory behind the method or trying to convince us to use the method. Which can waste time."

Group accountability by Active Reporting - Another major aspect of the workshops that faculty stated they benefited from and they felt a sense of mutual accountability that arose between the members over the summer. One aspect that may have contributed to this was as the beginning of every meeting, prior to the invited speaker, each member of the group gave a 1-minute update on the progress of their project and then stated what they hoped to work on next. Faculty reflected that this created a more regular accountability that helped them be more consistently productive. They also credited the group with increasing their ingenuity and productivity. One faculty member commented that "It was helpful to receive feedback from other faculty. I was given comments that greatly helped me tailor my assessments. It was also nice to see what other people's projects were. It gave me ideas for some of my other classes.” Everyone reported that they were more productive on course changes than they would have been without the summer group. 
Stipend - Finally, many faculty expressed that the stipends were appreciated, but were not a large motivating factor in their initial decision to participate in the workshop. Many faculty stated they were self-motivated to apply for the workshop, but the stipend was a strong motivator to consistently work on the project throughout the summer because faculty felt obligated to deliver timely and quality work to earn the payment. It also signified to faculty the college's commitment to teaching excellence. One faculty stated that the stipend was “...Important, but I don't know that the exact dollar value really mattered. But, having the college demonstrate an interest in investing in us as teachers and our courses is sometimes all it takes to prompt us to go above and beyond the norm."

Most of the suggested changes from the 2019 participants were relatively minor. Participant consensus was that the content, scope, and timing of deliverables and required level of attendance and participation were all appropriate and helpful. One participant thought they would benefit more if sessions could be offered on a discipline-specific basis, which could be addressed by having a few additional sessions focused on topics specifically of interest to instructors of, for example, computer science/programming courses or to first semester introductory courses. There were a few requests for specific topics of a participant's personal interests, which will gladly be considered. Another faculty suggested polling participants for topics of interest in advance of beginning the workshop.

The authors would like to implement in future workshops a requirement for faculty to include in their assessment plans a common survey on student attitudes towards student-active pedagogies. A final major future change will be that when the ECliPSE grants ends the current funding for the workshop will need to be replaced by college funds, and so will likely be reduced. This could be accomplished simply by reducing individual faculty compensation for participation, which seems feasible since faculty were near-unanimous in declaring that the specific amount was less important than compensation at all. Another option is to set higher acceptance standards, ranking applicants on a competitive basis rather than just needing to meet the application requirements, then accepting fewer applicants into the program.

Overall, the 2019 Course Redesign Summer Working Group was a success, in that it supported the goal of the ECliPSE program to provide opportunity and support for engagement of faculty in educational reform across the College. The ECliPSE grant committee is currently working to solidify this program as a permanent offering in the college on a biennial basis.

\section{References}

[1] Richard M. Felder R.M., Learning and Teaching Styles in Engineering Education, Engr. Education, 78(7), 674-681 (1988).

[2] Rugarcia A, Felder R.M., Woods D.R., Stice J.E., The Future of Engineering Education I: A Vision for a New Century, Chem. Engr. Education, 34(1), 16-25 (2000). 
[3] Felder R.M., Woods D.R., Stice J.E., Rugarcia A., The Future of Engineering Education II: Teaching Methods that Work, Chem. Engr. Education, 34(1), 26-39 (2000).

[4] Prince M., Does Active Learning Work? A Review of the Research, Journals of Engineering Education, Volume 93, Issue 3 Pages 223-231 (2004).

[5] Bonwell, C.C., and J. A. Eison, "Active Learning: Creating Ex-citement in the Classroom," ASHEERIC Higher Education Report No.1, George Washington University, Washington, DC, 1991.

[6] Smith, B., and J. MacGregor, "What is Collaborative Learning?,"in Goodsell, A., M. Mahler, V. Tinto, B.L.Smith, and J. MacGreger,(Eds), Collaborative Learning: A Sourcebook for Higher Education (pp. 9-22).University Park, PA: National Center on Postsecondary Teaching, Learning and Assessment, 1992.

[7] Millis, B., and P. Cottell, Jr., "Cooperative Learning for HigherEducation Faculty," American Council on Education, ORYX Press, 1998.

[8] Kwan A., Problem Based Learning, Chapter 8, The Routledge International Handbook of Higher Education, Edited by Malcolm Tight, Ka Ho Mok, Jeroen Huisman and Christopher C. Morphew, published 2009 Routledge, New Your, NY.

[9] Rebecca Brent, Richard Felder, Thomas Regan, Ardie Walser, Chris Carlson-Dakes, Donald Evans, Cesar Ma lave, Katherine Sanders, Jack McGourty, Engineering Faculty Development: A Multicoalition Perspective, Annual Meeting of the American Society for Engineering Education St. Louis, MO, June 18-21, 2000.

[10] K. Sanders, C. Carlson-Dakes, K. Dettinger, C. Hajnal, M. Laedtke, and L. Squire, "A New Starting Point for Faculty Development in Higher Education: Creating a Collaborative Learning Environment," in D. DeZure (Ed.), To Improve the Academy, v. 16, Stillwater, OK, New Forums Press, 1997, pp. 117-150.

[11] J.F. Fines, T. M. Regan, and K. K. Johnson, "Building Community Through a Freshman Introduction to Engineering Design Course: The ECSEL Teaching Fellows Program." 1995 ASEE Annual Conference Proceedings, 2358-2362, ASEE, June 1995.

[12] NSF DUE \#1323258

[13] C. Pfund et al., Professional development. Summer institute to improve university science teaching. Science (New York, N.Y.) 324, 470 (2009).

[14] National Effective Teaching Institutes, viewed on February 3, 2020, https://www.asee.org/education-careers/continuing-education/courses-and-workshops/neti. 
[15] NSF DUE \#1317540

[16] Katie D. Cadwell, Michelle M. Blum, Julie M. Hasenwinkel, Carol Stokes-Cawley. "A Gateway Course Redesign Working Group." Proceedings of the American Society for Engineering Education 2018 Annual Conference and Exposition, Salt Lake City, UT, 2018. 